\title{
Writing Political Biography
}

\section{Rae Wear}

Writing political biography almost always involves a degree of self-exploration: there is a little bit of autobiography lurking beneath the surface of every biography. To begin with, there is the choice of subject. Some biographers are drawn to personalities they admire while others tackle those they have little regard for but consider important or perhaps want to understand. Choosing a subject must involve reflection on the biographer's part about the reasons for their choice and also about the nature of the feelings they bring to the task. This reflection is essential if a biography is to be other than hagiography or a hatchet job. In my own choice of subject, Johannes Bjelke-Petersen, I was driven by a desire to understand the community in which I had lived most of my life and which had played a large part in my own political socialisation. Bjelke-Petersen was a man who had both shaped that community and been shaped by it. In growing up in provincial Queensland I had become acquainted with many of Bjelke-Petersen's men and women who in many respects were kindly churchgoers, yet who would think nothing of rorting their tax or doing slippery business deals. They always puzzled me, as Bjelke-Petersen did - that combination of rectitude and shady dealings.

I therefore set out with opinions ready formed. I had studied sufficient Queensland politics to know of his reputation for authoritarianism, contempt for Parliament and due process, rigging of the electoral system, and of the persistent rumours of corruption. In a timid and law-abiding fashion I had participated in protests against his curtailment of civil liberties in Queensland. The task for me as for any biographer was to try to understand him, and his success, rather than to give vent to the negative feelings I had accumulated. I imagine the obverse is true for those who set out to write about someone they admire. In trying to understand comes the recognition that the subject is a complex figure, neither all good nor all bad. Finding skeletons in the cupboard of an admired figure may be more difficult for a biographer to deal with than finding a human spark in a subject previously reviled.

There is a great deal of artifice in the biographer's work. A life is packaged, a story told, loose ends snipped off. The story is told as if it is the story. I have often wondered about applying to biography the device used in Akira Kurosawa's famous film Rashomon and the novels that comprise Laurence Durrell's Alexandria Quartet. These works describe the same events from multiple viewpoints and highlight the difficulty associated with producing a 'true' version of anything. A reliable biographer takes account of conflicting points of view, and checks 
and confirms data, but in the end the form demands a coherent and well ordered package which never mirrors the messiness of a subject's life. In my own work, I tried to convey some of the complexity of my subject's life by avoiding an historical narrative and examining Bjelke-Petersen's premiership through a series of relationships with a range of political institutions. I found, however, that historical narrative crept in through the back door, so I do not judge this to be a totally successful strategy

This problem of dealing with a range of conflicting viewpoints about a subject may be exacerbated by the use of interviews. Both James Walter and Judith Brett have written admirable biographies without doing interviews although, as Brett points out in the Introduction to Political Lives, some critics took them to task about this. Not using interviews certainly removes a lot of static, and means that a biographer is relying for evidence on stable historical sources rather than on frequently biased, unreliable and frequently unverifiable recollections. Interviewing the subjects' friends, enemies, acquaintances and colleagues inevitably places the biographer in a Rashomon-like situation, where all and sundry present their truthful but conflicting points of view. It may be the case that some interviewees try deliberately to mislead but I believe they are in the minority. Most people tell the story as they see it, but they rarely see the same thing because they have experienced different facets of a subject's personality. Bjelke-Petersen, for example, appeared to be benign and kindly until he was crossed. His supporters remain intensely loyal and appear never to have seen his angry and vindictive side. Reconciling divergent views about a subject does make the biographer's task difficult. Matters of fact can be checked, and the interviewee's relationship with the subject taken into account to try to establish the truth of the matter, but it is a challenge to present a multi-faceted personality in a coherent fashion and not lose the multi-faceted quality.

Sometimes I felt compromised by having accepted an interviewee's hospitality. In no case was this any more than a cup of tea and a slice of cake, but it made it so much harder to be critical. Bjelke-Petersen was famous for disarming his critics. Bob Ellis in Goodbye Jerusalem describes how he was absolutely enchanted by Sir Joh during a visit to Bethany, the Bjelke-Petersen property. In my own book I retell a story told by the late Andrew Olle who, as a current affairs reporter, accompanied Sir Joh on a flight to the Torres Strait. Andrew mentioned that he would have to make an early start the following morning, and was greeted at sunrise by the premier bearing a cup of tea. Undoubtedly Bjelke-Petersen had learnt the advantages that such actions can bring. As Pat Weller has observed, contacts of this kind reveal the human side of the interviewee and these glimpses of humanity are what can make it so hard to be a critic. I think this is true, but the act of 'breaking bread' and accepting hospitality compounds the problem. 
Considering all this, is it worth doing interviews especially when there is the added consideration that politicians are adept at avoiding giving much away in interviews? This is particularly true of serving politicians and I would probably never bother interviewing them for the purpose of biography. Sometimes, however, politicians become more expansive in retirement. Occasionally they feel they 'want to get matters on to the public record' or, more often, they want to settle old political scores. Sometimes some interesting insights emerge that have never been committed to the written record. Certainly interview material can add colour, interest and the occasional quirky gem. My own favourite from the Bjelke-Petersen biography came from an interview with the premier's first media adviser, Hugh Bingham:

I was sitting in the nice little premier's dining room and the cook came in with this beautiful tureen. The table was beautifully set with wine glasses and he lifted up the top of the tureen and it was boiled pumpkin and potatoes. Beautifully set out. They were just flawless. Absolutely flawless pumpkins and potatoes.

The image of those flawless vegetables has stayed with me with their revelations of the premier's asceticism, and the trappings of power.

Biography is a difficult craft. While there are many good political biographies, there are very few great ones. Too often it seems that years of careful research fail to grasp the subject's elusive essence. Fiction often seems to do a better job of this. For example, none of the biographies of Huey Long that I have read captures the man's essence nearly as well as Robert Penn Warren's All the King's Men (1946). A similar comment was made about my book Johannes Bjelke-Petersen, the Lord's Premier (2002). One reviewer observed that Andrew McGahan's Last Drinks (2000) captures the politics Bjelke-Petersen's Queensland more effectively than my own book. I think he may have been right, but at this point I can only reply that I was not writing fiction. Next time, though, I would like to bring something more to the process of political biography, and be a little more adventurous in marrying art with craft. 